
Mariana R Camargos $^{1}$
Gilberto M Jannuzzi $^{2}$
Muriel O Gavira $^{3}$
JEL: L94

DOI: 10.5937/industrija42-5131

UDK: 502.131.1:620.9(81) ; 620 . 9(81)

Original Scientific Paper

\title{
Analysis of the sustainability reporting initiatives of electric utilities in Brazil ${ }^{4}$
}

Article history:

Received: 14 November 2013

Sent for revision: 2 December 2013

Received in revised form: 4 January 2014

Accepted: 15 January 2014

Available online: 28 March 2014

\begin{abstract}
In an effort to attend to the growing concern about the social and environmental impact of organizational activities, several companies have begun to publish corporate sustainability reports. Brazilian power sector, following a worldwide trend, has the great majority of its companies using the Global Reporting Initiative (GRI) framework as a model for sustainability reporting. A different model of Corporate Social Report is also required, by law, by the Brazilian National Agency of Electric Energy (ANEEL). In this context, the objective of this paper was to assess how Brazilian electricity utilities are using GRI guidelines and the effect of legislation on the content of this report. For this, an exploratory and comparative study was carried out on the sustainability reports of 12 electric utilities. The indicators used and the content of the 2010 reports were analyzed and compared, in order to verify the presence of a pattern in which the distributors use the guidelines and its indicators. The first findings show that the adopted sustainability concept, the adequacy to the GRI principles, the choice of indicators and the quality of the information reported are quite variable among different companies. The influence of ANEEL on the content of GRI report became quite clear. It is possible to conclude that GRI model is not, in a general way, well used by Brazilian electricity companies, showing there is much to be done to advance sustainability reporting in this sector, especially in relation to transparency and quality of the reports.
\end{abstract}

\footnotetext{
${ }^{1}$ University of Campinas, Department of Energy, Brazil and International Energy Initiative - IEI, e-mail: mariana@iei-la.org

${ }^{2}$ University of Campinas, Faculty of Mechanical Engineering, Brazil and IEI

${ }^{3}$ University of Campinas, School of Applied Sciences, Brazil

${ }^{4}$ CAPES; This paper was presented on the 7th Conference on Sustainable Development of Energy Water and Environmental Systems - SDEWES, held from July 1 - 7, 2012 in Ohrid.
} 
Camargos M.R. et al.: Analysis of the sustainability reporting initiatives of electric...

Keywords: Brazil; Reporting; Environmental sustainability; Electricity

\section{Analiza inicijativa izveštavanja o održivosti u elektro privredi Brazila}

Apstrakt: U nastojanju da skrenu pažnju na sve veću zabrinutost povodom socijalnog i ekološkog uticaja organizacionih aktivnosti, određene kompanije su počele da objavljuju izveštaje o održivosti. Prateći svetski trend, velika većina kompanija iz brazilskog sektora za snabdevanje električnom energijom koristi okvir za Globalnu inicijativu izveštavanja (GRI) kao model za izveštavanje o održivosti. U skladu sa zakonom, brazilska Državna agencija za električnu energiju (ANEEL) zahteva drugačiji model Izveštavanja o korporativno društvenoj odgovornosti. U tom kontekstu, cilj ovog rada je bio da se proceni kako kompanije brazilske elektroprivrede koriste GRI smernice $i$ uticaj zakonskih propisa na sadržaj ovog izveštaja. U tu svrhu je sprovedeno komparativno istraživanje izveštaja o održivosti iz 12 elektroprivrednih kompanija. Analizirani i poređeni su pokazatelji iz izveštaja iz 2010.godine kako bi se proverilo da li postoji obrazac po kom distributeri koriste smernice $i$ svoje pokazatelje. Prvi rezultati pokazuju da usvojeni koncept održivosti, usklađenost sa GRI principima, izbor pokazatelja $i$ kvalitet objavljenih informacija variraju u različitim kompanijama. Pojašnjen je i uticaj ANEEL-a na sadržaj GRI izveštaja. Uopšteno govoreći može se zaključiti da brazilske elektroprivredne kompanije nisu na dobar način koristile GRI model što ukazuje na činjenicu da se izveštavanje o održivosti u ovom sektoru mora unaprediti, posebno u pogledu transparentnosti i kvaliteta izveštaja.

Ključne reči: Brazil; izveštavanje; održivost životne sredine; struja

\section{Introduction}

In the last two decades, the public, governments, customers and other stakeholders have demonstrated increasing awareness about the social and environmental consequences of human activities in general, particularly those resulting from business operations. As a result, there is growing expectation from companies to assume their social and environmental responsibilities and adjust their business practices in order to mitigate the negative impacts of their operations, while contributing to the communities in which they operate (Juholin, 2004). Research in this area shows that many companies are responding to these demands by implementing various sustainability initiatives in their activities. Because of that, it is possible to see positive trends such as the growing number of companies that takes initiatives in Corporate Sustainability and the rising number of structures and guidelines developed to support the efforts of companies to become socially responsible (Grasbois, 2012) 
Camargos M.R. et al.: Analysis of the sustainability reporting initiatives of electric...

Roca and Searcy (2012) state that there is no universal definition of Corporate Sustainability. It can be considered as a synonym of Corporate Social Responsibility (CSR), which can be defined as "adopting business strategies and activities that meet the need of the enterprise and its stakeholders today while protecting, sustaining and enhancing the human and natural resources that will be needed in the future" (IISE, 1992). Stakeholders not only require companies to implement responsible practices, but also to provide access to information about the scope and effectiveness of adopted social responsibility initiatives (Grasbois, 2012). However, traditional financial accounting and reporting do not adequately provide for the measurement of social and environmental impact, so that there is a need for broader reporting in organizations (Roca, and Searcy, 2012; Yongvanich and Guthrie, 2006).

Sustainability reports, which integrate accounting on environmental, social and economic issues into so called triple bottom line accounting (Elkington, 1998), emerge as an attempt to create a communication channel with stakeholders. The information disclosed on those reports is often used in the process of decision making by investors, governments and customers. Thus, according Juholin (2004), the concept of Corporate Social Responsibility also includes the transparency of companies, as well as consideration to the wishes and expectations of stakeholders. According to the author, the companies work best when their interests are reconciled with the stakeholders'. Gray (2010) have questioned if concepts like sustainability or sustainable development can actually be applied to the corporate level. According to this author, an issue of concern is that through uncritical repetition the terms may be thought to be entering common discourse emasculated and largely trivialized (Gray, 2010).

Yet, in an effort to attend to the increasing stakeholder's interest in those issues, several companies are publishing corporate sustainability reports. This activity has been seen as a way for companies to manage public impressions of the organization's operations in order to establish or maintain organizational legitimacy (Hedberg and Malmborg, 2003). Other examples of reasons for reporting were summarized by Kolk (2010) and include "enhanced ability to track progress against specific targets", "greater awareness of broad environmental issues", "improved all-round credibility from greater transparency", "license to operate and campaign", "reputational benefits", "cost savings identification", and "enhanced staff morale", among others.

The emergence of such reports has been accompanied by numerous attempts over the years to standardize such practices, with the Global Reporting Initiative (GRI) being the primary mover in establishing international standards for non-financial reporting (Skouloudis et al., 2010). GRI is the bestknown and more complete framework for voluntary reporting of environmental and social performance by business and other organizations worldwide 
Camargos M.R. et al.: Analysis of the sustainability reporting initiatives of electric...

(Brown et al., 2009; Lozano and Huisingh, 2011). It was established in 1997 by a number of companies and organizations belonging to the Coalition for Environmentally Responsible Economies (CERES), with the mission of developing globally applicable voluntary guidelines for reporting on economic, environmental and social performance, initially for corporations and eventually for any business or governmental or non-governmental organization (Lamberton, 2005). The components of GRI reporting framework are the Guidelines for Sustainability Reporting, the Performance Indicators, the GRI Application Levels and the Sector Supplements (GRI, 2006).

While one of the key strengths of the GRI has been to help popularize a multistakeholder process in sustainability reporting, it has been widely criticized (Roca and Searcy, 2012). Moneva et al. (2006) state that preliminary evidence from practice seems to show that GRI guidelines are used in a biased way. According to the authors, some organizations that label themselves as GRI reporters do not behave in a responsible way with respect to social or human rights (Moneva et al., 2006). Another negative point is the fact that the informal nature of the guidelines and the permission to include additional information allow organizations to select which information will be disclosed. This can lead to an inaccurate representation of the organization's activities. Guthrie and Farneti (2008) showed that organizations chose carefully which data would be disclosed in its annual report, which contradicts the expectations of stakeholders regarding the transparency of information.

Therefore, it is important to investigate the use of GRI guidelines in different business sectors. In this context, the objective of this paper is to present the findings of a qualitative and explorative research that analyzes the sustainability reporting initiatives of Brazilian electric utilities. As several of these companies have chosen the Global GRI framework as a model for sustainability reporting, this paper evaluates how GRI guidelines are being used by electricity utilities in Brazil.

\section{Research Methodology}

To evaluate how the GRI guidelines are being used by electricity companies in Brazil, an exploratory and comparative study was carried out on the sustainability reports of 12 electric utilities. The indicators used and the content of the 2010 reports were analyzed and compared, in order to verify the presence of a pattern in which the distributors use the guidelines and its indicators. It was also checked if the reports follow the GRI principles, if the indicators mandatorily required by National Agency for Electricity (ANEEL) influence the GRI report and if the guidelines are a good model for Brazilian electricity companies. 
Camargos M.R. et al.: Analysis of the sustainability reporting initiatives of electric...

\subsection{Selection of the companies}

As a scope, only the electric utilities' reports were assessed. Selected companies were members of at least one of these associations: Brazilian Association of Electricity Distributors (ABRADEE), Brazilian Association of Electricity Transmitters (ABRATE) and Brazilian Association of Electricity Generator (ABRAGE). These associations' members are responsible for almost the entire generation, transmission and distribution of electricity in the country. From this list, it was possible to found a clear preference for the GRI framework, among companies that published sustainability reports. However, this study considered only the companies that were at the list available at GRI website. Selected companies were only the ones with report containing GRI content index, which characterizes a report made in the GRI model. Analysis included only those companies that, by the year 2010, had already published at least two GRI reports. The companies selected are listed in TABLE 1 that also shows the level of application of the GRI guidelines. Upon finalization of report, companies should self-declare the level to which they have applied the GRI Reporting Framework. "+" indicates that the report was submitted to external evaluation by third parties.

Table 1. Companies assessed

\begin{tabular}{|l|l|}
\hline Company & GRl level \\
\hline AES & $\mathrm{B}$ \\
\hline CELPE & $\mathrm{C}$ \\
\hline CEMIG & $\mathrm{A}+$ \\
\hline COELBA & $\mathrm{A}$ \\
\hline COSERN & $\mathrm{C}$ \\
\hline CPFL & $\mathrm{A}$ \\
\hline ELEKTRO & $\mathrm{B}$ \\
\hline ELETROBRAS & $\mathrm{B}+$ \\
\hline ENDESA & $\mathrm{A}$ \\
\hline LIGHT & $\mathrm{A}$ \\
\hline REDE & $\mathrm{B}$ \\
\hline TRACTEBEL & $\mathrm{A}+$ \\
\hline
\end{tabular}

Source:Author

\subsection{Aspects analyzed}

Adequacy to GRI principles: To see if GRI guidelines were used adequately by the companies, it was verified if four principles defined by GRI were obeyed. The principles analyzed are the ones described in TABLE 2. 
Camargos M.R. et al.: Analysis of the sustainability reporting initiatives of electric...

Table 2. GRI principles analyzed

\begin{tabular}{|c|c|}
\hline Principle & Description \\
\hline Sustainability Context & $\begin{array}{c}\text { Reports should present performance in relation to } \\
\text { broader concepts of sustainability. It must be } \\
\text { specified how the organization contributes or intends } \\
\text { to contribute in the future to the improvement or } \\
\text { deterioration of economic, environmental and social } \\
\text { issues at local, regional and global levels. }\end{array}$ \\
\hline Balance & $\begin{array}{c}\text { The report should reflect positive and negative } \\
\text { aspects of the organization's performance to enable a } \\
\text { reasoned assessment of overall performance. }\end{array}$ \\
\hline Comparability & $\begin{array}{c}\text { Reported information should be presented in a } \\
\text { manner that enables stakeholders to analyze } \\
\text { changes in the organization's performance over time, } \\
\text { and could support analysis relative to other } \\
\text { organizations. }\end{array}$ \\
\hline Clarity & $\begin{array}{c}\text { Information should be made available in a manner } \\
\text { that is understandable and accessible to stakeholders } \\
\text { using the report. }\end{array}$ \\
\hline
\end{tabular}

Source:Author

The number of indicators used by each company: By comparing the number of indicators of each category used in each GRI report, it was checked if there was uniformity in the way the GRI guidelines were used by the companies. These categories are the dimensions proposed by GRI: Economic, Environmental and Social (the latter being divided into Labor Practices and Decent Work, Human Rights, Society and Product Responsibility). In this paper, the indicators of Electric Utility Sector Supplement are not included.

The influence of ANEEL's requirements in the GRI report: It was also checked if the mandatory report required by ANEEL could influence the indicator's choice by companies in the reporting process.

\section{Results}

\subsection{Overview of Sustainability in Brazilian Electric Sector}

In Brazil, $97 \%$ of the population has access to safe and regular electricity (Pereira et al., 2010). According to the National Agency of Electric Energy (ANEEL), Brazil has more than 61 million units consuming electricity, of which $85 \%$ are residential (ANEEL, 2006). Electricity consumption is unevenly distributed throughout the country. Only the Southeast, according to the National Energy Balance 2011, is responsible for over 50\% of residential 
Camargos M.R. et al.: Analysis of the sustainability reporting initiatives of electric...

electricity consumption (EPE, 2011). The other regions, although displaying a growth in recent years, are responsible for a portion considerably lower of the consumption.

The electricity generation matrix in Brazil is predominantly renewable, with hydropower accounting for $74 \%$ of supply. Considering the imports, which are mainly from renewable sources, it can be stated that approximately $85 \%$ of electricity in Brazil is generated through renewable sources - not to mention that part of the thermal generation comes from biomass (EPE, 2011).

The Brazilian electric utilities are an example of a group that suffers great pressure from different stakeholders to become socially and environmentally responsible. The reason for that is that the electricity sector is classified as a sensitive industry: at the same time it works as an engine of economic development, it produces high level of environmental and social impacts, both in the construction of hydroelectric plants, as in the operation of power plants and nuclear (Braga, 2011).

That may explain why, in Brazil, a significant share of companies that use the GRI reporting framework belongs to the energy sector. As it is possible to see in the Figure 1, the energy sector accounts for $25 \%$ of total GRI reporting companies.

Figure 1. Number of companies, by sector, that uses the GRI framework $(G R I, 2006)$

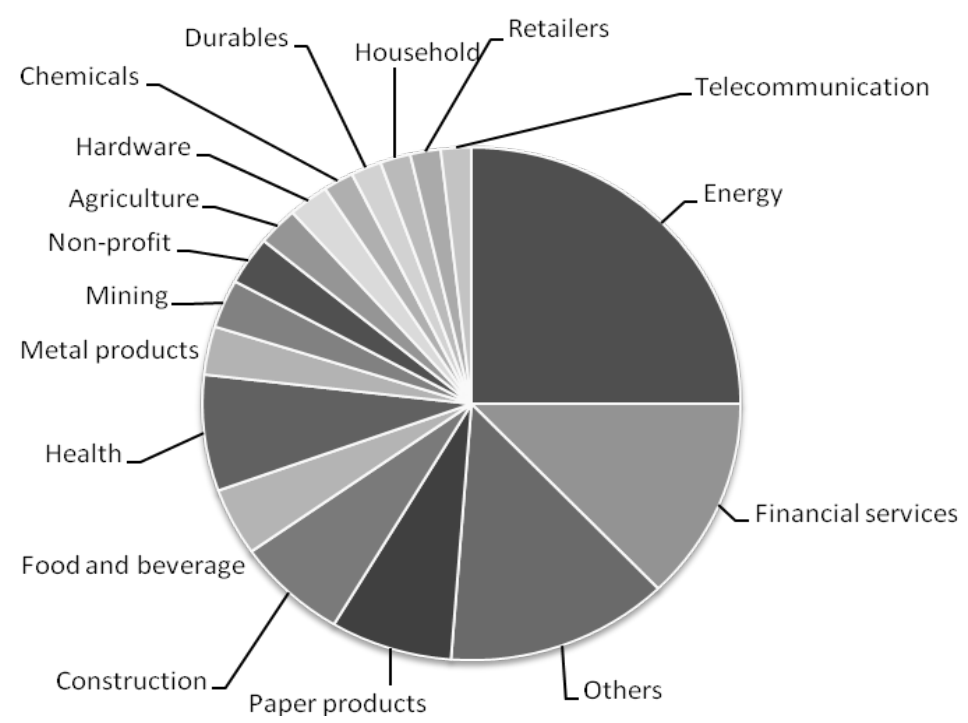

Source:Author 
Camargos M.R. et al.: Analysis of the sustainability reporting initiatives of electric...

Apart from GRI reporting, most Brazilian electric utilities commit themselves with global agreements, such as the United Nations Global Compact and the Eight Millennium Development Goals, and are interested in taking part of the sustainability indexes, as the Dow Jones Sustainability Index (Dow Jones Sustainability Indexes, 2012) and the Corporate Sustainability Index of Bovespa (ISE, 2012).

In addition to the indicators proposed by GRI, those companies also use the indicators required by National Agency for Electricity (ANEEL), the Brazilian power regulator. These indicators are present in the "Manual for Development of Social Responsibility Annual Report of Electric Utilities", published by ANEEL in 2006. This manual also provides the necessary guidelines for the elaboration of the mandatory social and environmental reports that the companies should submit annually to the Regulatory Agency. The indicators proposed are divided into social, economic, environmental and sectoral dimensions, similar to the GRI framework. They aim to show relevant information on these dimensions, considering the reality of the Brazilian electric sector.

ANEEL's proposed report is a minimum standard to be developed by companies. According to the regulator, the companies can then choose producing a report based on broader patterns, such as the GRI model, provided it uses all the indicators and the information required in the manual.

It is important to note that, although the GRI model is wider in scope, ANEEL's manual provides more specific indicators to the Brazilian electric sector, requiring more quantitative data than GRI requires. Some indicators, however, are coincident between the two models.

\subsection{General findings}

The study's findings show heterogeneity in the adopted sustainability concept and differences in the choice of indicators by companies, which is demonstrated in the following sections. The quality of the information reported is also quite variable among different companies.

It was observed that, because it is an obligation, the indicators present in the ANEEL guide are more commonly used in the reports of all utilities. On the other hand, GRI indicators, which are voluntary, are used differently between companies. It is also very common the commitment of the companies with the Global Compact Principles (United Nations Global Compact, 2011), even though all the topics of this agreement are covered by GRI indicators. Some companies also follow the Eight Millennium Development Goals (MDG), proposed by the United Nations (Millennium Development Goals, 2011). Unlike the Global Compact, MDG are additional to what GRI proposes and 
Camargos M.R. et al.: Analysis of the sustainability reporting initiatives of electric...

can improve companies' initiatives with social responsibility, and thus, enrich the report.

\subsection{The adequacy to GRI principles}

\subsubsection{Context of Sustainability}

According to GRI, the report should present the organization's performance in a broader context of sustainability. That is, evaluating and reporting the company's performance within the limits and demands of environmental or social resources at local, regional or global levels. It is interesting, though, to observe that the concepts of sustainability that the analyzed companies adopt are frequently different from what GRI proposes. TABLE 3 presents the understanding of sustainability by companies.

Table 3. Adopted concepts of sustainability by companies

\begin{tabular}{|c|c|}
\hline Company & Concept of sustainability \\
\hline AES & Security, efficiency in resources use, development of community. \\
\hline CELPE & Social responsibility. \\
\hline CEMIG & $\begin{array}{l}\text { Guidance of their actions in a long time horizon. Management of } \\
\text { environmental, economic and social development. }\end{array}$ \\
\hline COELBA & $\begin{array}{l}\text { Continuous improvement of its performance in the economic, social } \\
\text { and environmental dimensions. }\end{array}$ \\
\hline COSERN & $\begin{array}{l}\text { Preservation of environmental resources, socially responsible } \\
\text { management, search for financial results that promote human } \\
\text { development at the same time. }\end{array}$ \\
\hline CPFL & $\begin{array}{l}\text { Worry over the future consequences of their actions and decisions. } \\
\text { Management of social, economic and environmental impacts. }\end{array}$ \\
\hline ELEKTRO & $\begin{array}{l}\text { Ensuring continuity of operations and balance on social, } \\
\text { environmental and economic aspects to promote continuous } \\
\text { improvement in all processes of the company. }\end{array}$ \\
\hline ELETROBRAS & $\begin{array}{l}\text { Achieving the economic-financial, social and environmental } \\
\text { operations, without compromising the quality of life of future } \\
\text { generations. }\end{array}$ \\
\hline ENDESA & To improve social, environmental and economic performances. \\
\hline LIGHT & $\begin{array}{l}\text { Human, social and economic growth to all its stakeholders, including } \\
\text { the respect for the environment. }\end{array}$ \\
\hline REDE & $\begin{array}{l}\text { Management of the results of its business in the environmental, } \\
\text { economic and social development. Promoting local development, } \\
\text { which would in the long-term, promote the growth of the company. }\end{array}$ \\
\hline TRACTEBEL & $\begin{array}{l}\text { Respect to people, environment and institutions. Improvement of the } \\
\text { management on social, environmental and economic dimensions. }\end{array}$ \\
\hline
\end{tabular}

Source: Author's calculation 
Camargos M.R. et al.: Analysis of the sustainability reporting initiatives of electric...

Despite the differences in the sustainability concepts, it is possible to see that almost all companies go through the triple bottom line concept, which involves people, planet and prosperity. That concept is consistent with the notion coined by IUCN 1980 World Conservation Strategy, that for development to be sustainable it must take into account social and ecological factors, as well as economic ones (IUCN, 1980).

However, except for CEMIG, CPFL and REDE, there is no mention of the notion of long-term in other companies' definitions. This differs from the broad concept of sustainability referred by GRI, which remembers the existence of limits on social and environmental systems.

Also, the companies fail to demonstrate its impacts at local and global levels. What it is possible to see in reports is an account of good practices of the companies, without, however, the description of their role in maintaining the systems in which they operate.

\subsubsection{Balance}

The principle of Balance was not obeyed by most companies. Negative information about the company is virtually nonexistent in the reports. Even if an indicator has indicated a worsening in performance (e.g., significant increases in water consumption from one year to another), this information is, in most cases, little explored in the text. It was observed that the reports lack explanations about what led to negative results or about which attitudes are being taken to change this picture. What was seen in the reports was, in general, a description of best practices and initiatives of companies without, however, the explanation about the failures and propositions of improvements.

\subsubsection{Comparability}

The principle of Comparability was used unevenly among companies. Some companies have demonstrated greater availability of historical data, presenting information of more than three periods prior to the reporting. However, most presented data are for the last three periods. Still there have been cases of companies that disclosed information relating only to the period covered by the report, which prevents comparability. With only the information of a single period, it is not possible to see how the performance of the organization has evolved over the years.

\subsubsection{Clarity}

Most reports followed the principle of Clarity, making information easy to understand by the public interest. However, it was observed that some companies presented aggregated data. This was the case for most of the holdings, which submitted without proper disaggregation, information on the companies under their control. There were also cases of companies that 
Camargos M.R. et al.: Analysis of the sustainability reporting initiatives of electric...

described the indicators very superficially, which prejudice the understanding of the readers.

\subsection{The number of indicators used by each company}

The findings show that there are significant differences in how the companies use the guidelines. An evidence of that is the difference in the number of indicators chosen by companies. The following graphics contain the quantity of indicators chosen by the 12 companies in each category. The total numbers of core and additional indicators proposed by GRI are in parenthesis.

Economic indicators. Considering the Economic dimension, the level of utilization of indicators is quite variable between companies. It ranges from $44 \%$ to $100 \%$, with only CEMIG, ENDESA and TRACTEBEL using all 9 existing indicators. CPFL and REDE used all core indicators. The only indicator that is used by all companies is EC1. The reason seems to be the fact that this indicator is coincident with the table required by ANEEL in the economic-financial dimension of the mandatory Social-Environmental Report.

Figure 2. Use of Economic indicators among companies

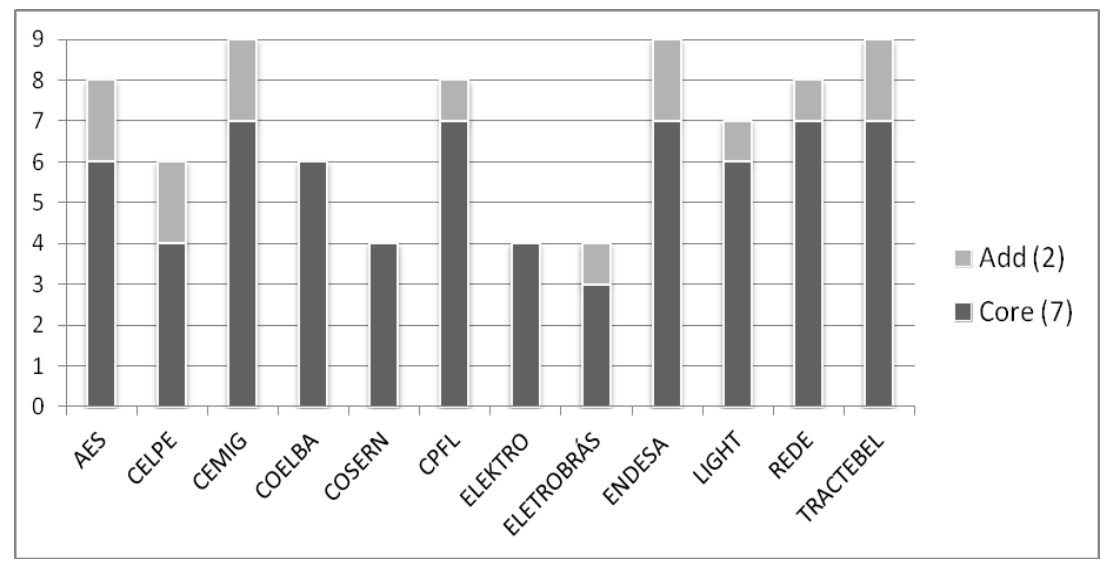

Source:Author calculation

Environmental indicators. The level of utilization of environmental indicators is even more variable than of economic indicators. It ranges from $33 \%$ to $93 \%$. None of the companies uses all the 30 existing environmental indicators. CPFL, ENDESA and LIGHT use all the core indicators. COSERN is the company that uses the lowest number of indicators. It is possible to see that the indicators EN12, EN14 and EN18 were used by all companies. All these three indicators are coincident with indicators proposed by ANEEL. 
Camargos M.R. et al.: Analysis of the sustainability reporting initiatives of electric...

Figure 3. Use of Environmental indicators among companies

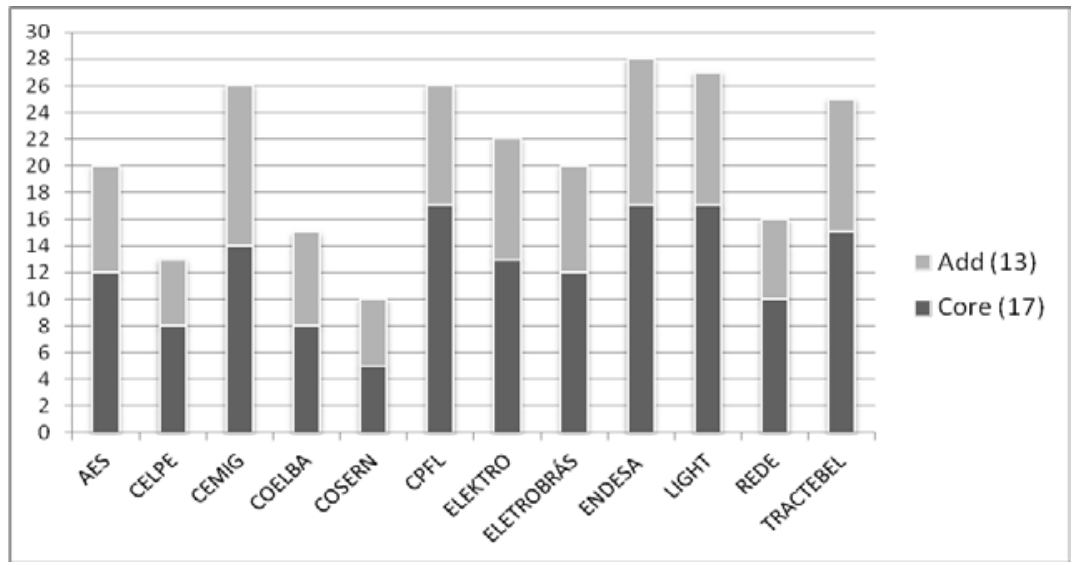

Source:Author calculation

Social indicators. The Labor Practices and Decent Work social indicators are well used by all the companies. Their use ranges from $78 \%$ to $100 \%$. CEMIG, CPFL and LIGHT use all the available indicators. A reason for this great level of utilization may be the fact that the majority of these indicators are required by ANEEL in the Social and Sectoral dimension of the mandatory report. Besides, most of these indicators are coincident with the social indicators of IBASE Social Balance, which are also required by ANEEL.

Figure 4. Use of Labor Practices and Decent Work indicators among companies

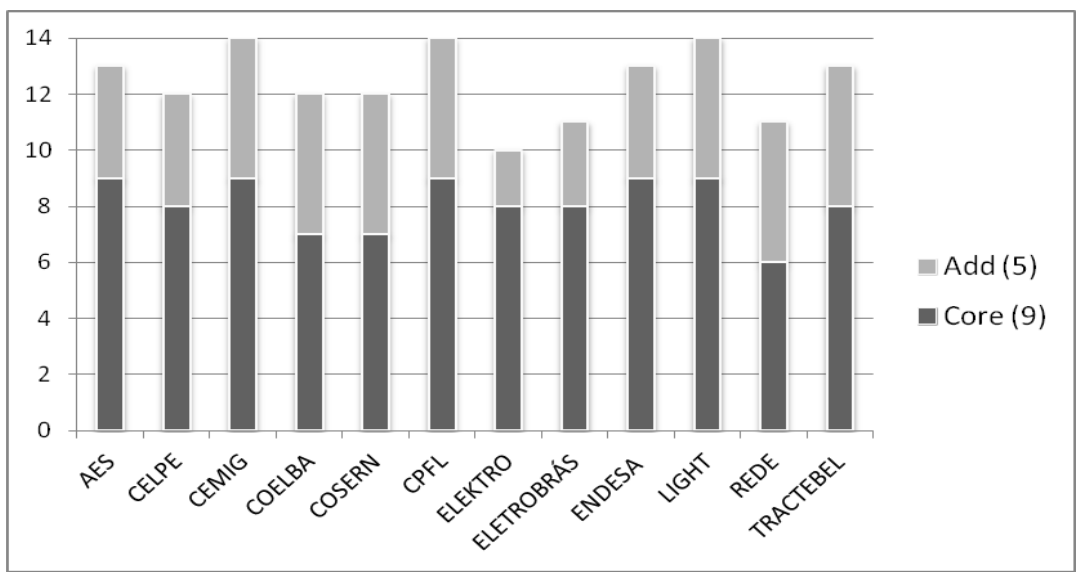

Source: Author calculation 
Camargos M.R. et al.: Analysis of the sustainability reporting initiatives of electric...

The Social indicators from Human Rights category are also widely used by companies, especially if we consider the core indicators. Their use varies from $44 \%$ to $100 \%$, but considering only the core indicators, it varies from $66 \%$ to $100 \%$. CPFL and TRACTEBEL use all the available HR social indicators. The most used indicators (HR2, HR6 and HR7) are also of mandatory use, according to ANEEL, which can explain their choice by companies.

Figure 5. Use of Human Rights indicators among companies (author calculation)

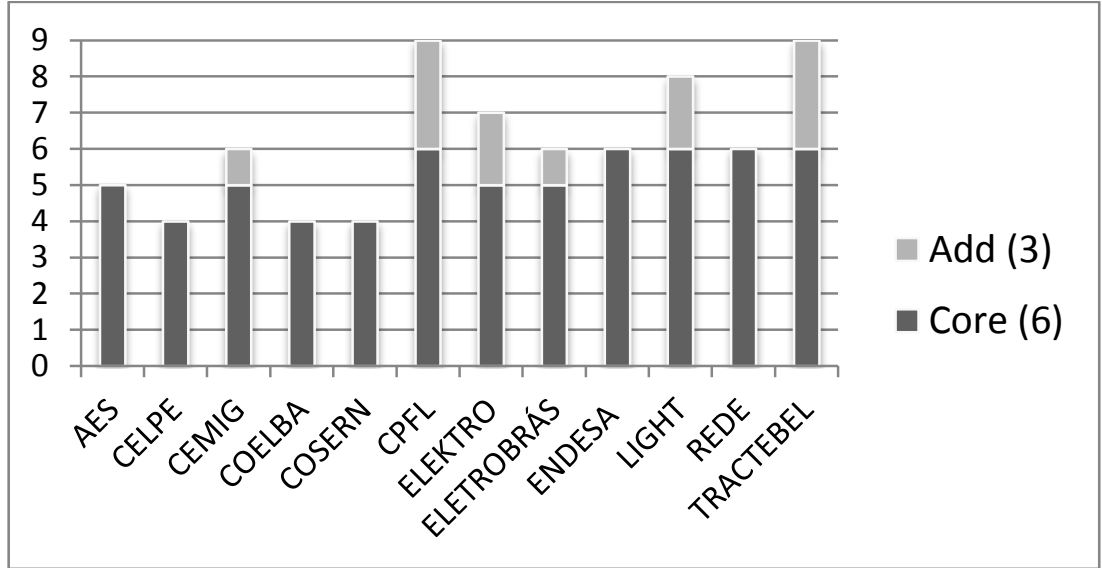

Source:Author

Figure 6. Use of Society indicators among companies (author calculation)

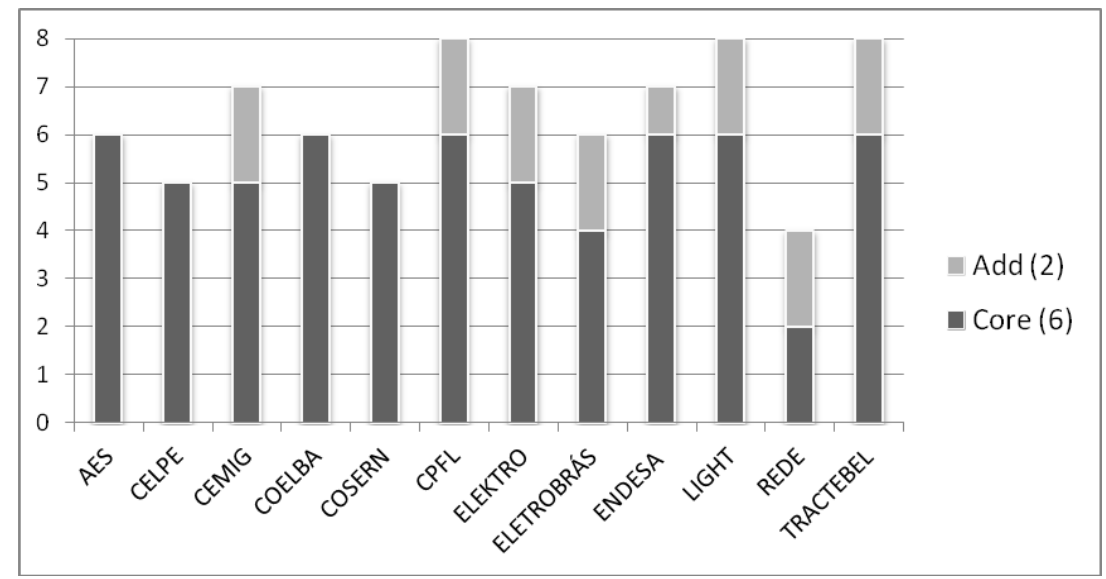

Source:Author 
Camargos M.R. et al.: Analysis of the sustainability reporting initiatives of electric...

The use of Society indicators ranges from $58 \%$ to $100 \%$. CPFL, LIGHT and TRACTEBEL use all of the 8 indicators of this category. SO1 is the indicator more commonly used by utilities. The choice of this indicator may also be explained by its mandatory use by ANEEL.

Product Responsibility indicators are not widely used by companies. Their level of use ranges from $22 \%$ to $100 \%$, with only two companies (CPFL and LIGHT) using all the nine existing indicators. PR5 is the only indicator of this category used by all companies and the reason is the fact that this indicator is about customer satisfaction, coincident with the ones proposed by ANEEL.

Figure 7. Use of Product Responsibility indicators among companies (author calculation)

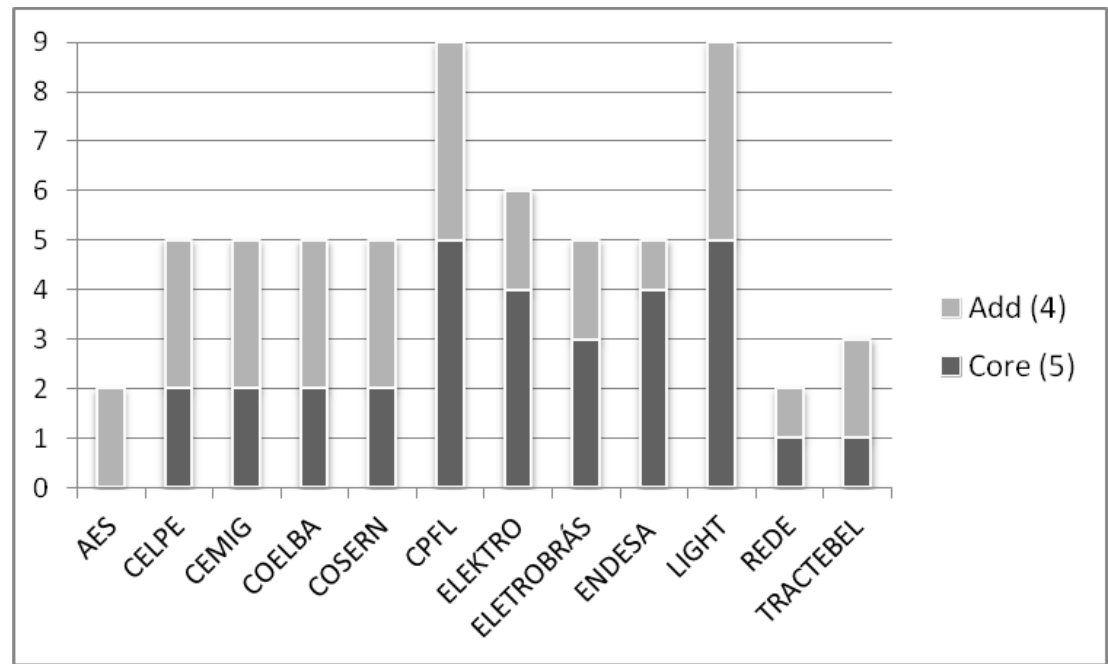

Source:Author

Figure 8 shows the percentage of use of the GRI indicators that exist for each dimension, by company. It is possible to see that only CEMIG, CPFL and TRACTEBEL use more than $80 \%$ of the indicators in three dimensions. It is also observed that there is no pattern in the use of indicators. In some companies there is a balance between dimensions, while others have a preference for a certain group. It is curious to observe that in none of the companies, there was a preponderance of environmental indicators. 
Camargos M.R. et al.: Analysis of the sustainability reporting initiatives of electric...

Figure 8. Percentage of GRI indicators used by distributors in each dimension (author calculation)

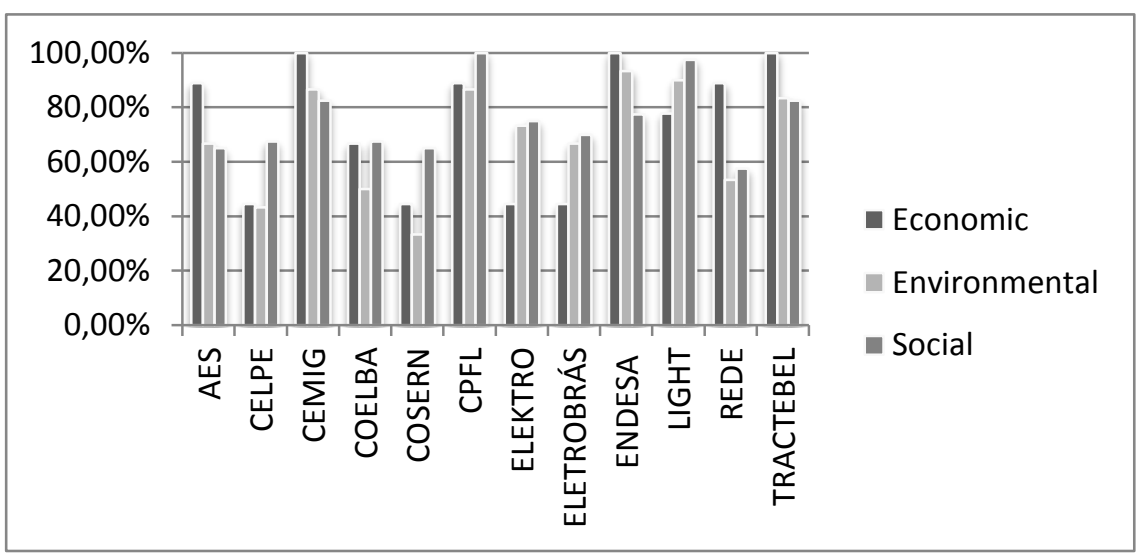

Source:Author

\subsection{The influence of ANEEL's requirements in the GRI report}

This part of the analysis aimed to understand if the Manual for the Preparation of the Environmental Report ANEEL influences the GRI report content published by companies. For this, indicators were divided into two groups: the ones that had a correspondent in ANEEL's manual and the ones that were exclusive of GRI guidelines. Then it was assessed the level of utilization of each indicator, which is, for each indicator, the percentage of companies that used it.

It was observed that, for the most part of GRI indicators that have a corresponding indicator in ANEEL's manual, the level of utilization is high. $35 \%$ of the indicators of this group were used by all the companies and $83 \%$ of the indicators were used by more than $80 \%$ of the companies.

The situation is different when we consider the indicators that are exclusive of GRI (not required by ANEEL). In this group, only $3 \%$ were used by all companies, and $32 \%$ were used by more than $80 \%$ of the utilities.

The contrasting results show a trend: GRI indicators that are also required by ANEEL have a high level of use, while the exclusive GRI indicators are less used by companies. It proves the influence of the mandatory report in the disclosure of GRI indicators. 
Camargos M.R. et al.: Analysis of the sustainability reporting initiatives of electric...

\subsection{Negative aspects}

Besides the failures in the commitment with the GRI principles, it is possible to highlight other negative aspects in the use of GRI by companies.

The first one is the misuse of GRI Application level. GRI suggests that, upon finalization of companies' report, they should declare the level to which they have applied the GRI Reporting Framework. They are titled C, B, and A, and the reporting criteria found in each level reflects an increasing application or coverage of the guidelines. It was observed that some companies, despite declaring themselves with the maximum level $(A)$ of application of GRI guidelines, they do not follow what this level requires (use of all core indicators and the explanation about the omitted ones).

Another failure observed in the reports is that, sometimes, the indicator is mentioned in GRI content index, but the information about this indicator cannot be found in the report text or it isn't reported following exactly what the GRI indicators protocols proposes.

\section{Discussion}

The analysis of the reports showed that although all companies use the same guide for the preparation of the document - the GRI guidelines - there was considerable heterogeneity among the publications.

Figure 9. Total number of indicators used by companies (author's calculation)

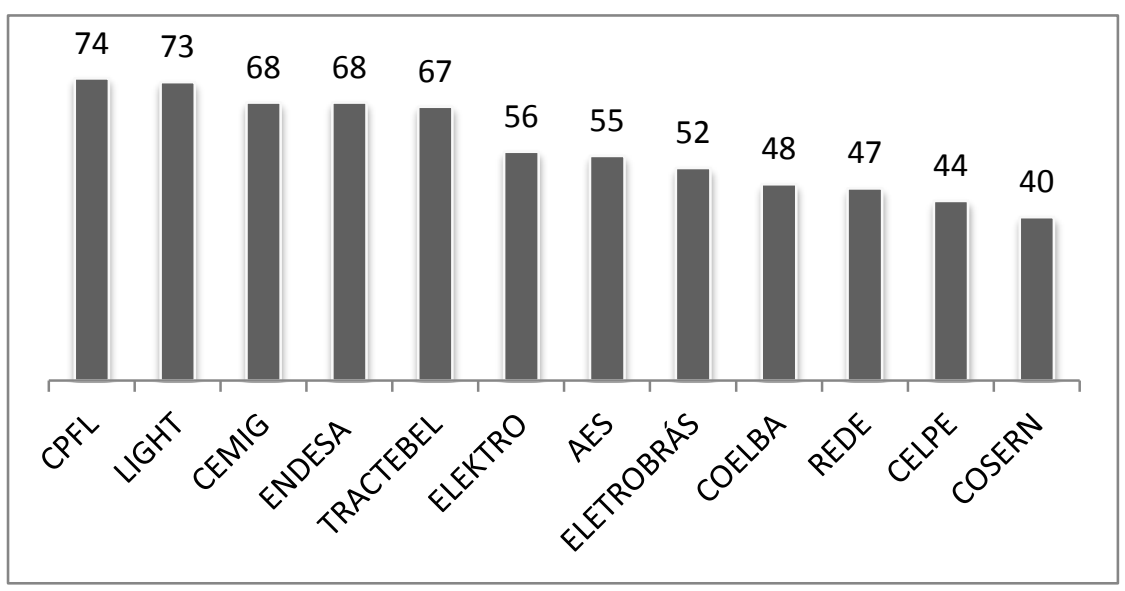

Source:Author 
Camargos M.R. et al.: Analysis of the sustainability reporting initiatives of electric...

Regarding the use of the guidelines, it was not observed, in general, a commitment of the companies to follow the principles established by GRI, and the reports were elaborated with great freedom. The fact that GRI does not require external verification of the sustainability report corroborates this practice. It is believed that the major problem of the lack of uniformity and external verification is the damage it causes to the comparability between companies. If some companies are not using the GRI guidelines properly, the comparability with those who seek to fit the model is hindered.

The findings also point to a mismatch between the understanding of sustainability as defined by GRI and Brazilian utilities. Although the analyzed companies follow the concept of triple bottom line, which includes social, economic and environmental dimensions, the majority of the reports lack the notion of long-term. The stakeholders are not clear with the companies' impacts at local, regional or global levels. Without the understanding that there are limits to their activities, companies fail to demonstrate how they can contribute to the deterioration or improvement of the environment where they operate. The reports seem to be, thus, only a description of good business practices in the social and environmental areas.

The choice of GRI indicators varies greatly among companies, as we demonstrate in Figure 9, which shows the total number of indicators selected by each company (among additional and essential indicators).

It is important to emphasize that the use of a greater number of indicators does not mean a better report. We believe, though, that the level of application of the guidelines is not a good basis for comparison, given it assesses how complete the use of GRI framework was by organizations and not how sustainable the company was. This means that an organization classified as level " $\mathrm{A}$ " is not necessarily more sustainable than the one evaluated as "B". This classification should not therefore be used as a standard reference, but as an internal feedback on how companies are progressing over time. However this information is, sometimes, used in biased way, creating a false marketing that deceptively reflects the performance of each organization in the pursuit of sustainability.

Besides the differences in the numbers of indicators, differences were noticed in the quality of reports. This diversity is probably due to the fact that GRI guidelines are voluntary and do not require external verification, which allows great liberty to companies. This flexibility, again, affects the comparability between the reports.

Because of that, external verification should be considered as an important step in the process of sustainability reporting. Some reports follow the GRI orientations and are more transparent than others, which report vague information and do not obey the GRI pattern. This way, a third party 
Camargos M.R. et al.: Analysis of the sustainability reporting initiatives of electric...

assessment could ensure, in part, the quality of the reports and the reliability of the data present, thereby increasing the commitment of companies in making better reports.

By analyzing the utilities' reports, it was observed that there was preference for some GRI indicators and that the preferred ones coincided with the indicators required by ANEEL, showing the great influence of the regulatory agency on shaping social and environmental reports. In fact, several GRI indicators are in accordance with the requirements of ANEEL. Thus, the use of GRI guidelines helps the companies meet their obligation with the regulatory agency and, at the same time, gives them the opportunity to report in a more fully way. ANEEL indicators, in turn, are adapted to the reality of the Brazilian electric sector, being, this way, an adequate guide to the sustainability reporting practices of these companies. It is believed that, when properly done, the combined use of the two frameworks can be quite positive.

\section{Conclusions and Recommendations}

From this research, it was possible to conclude that GRI is not, in a general way, well used by Brazilian electricity companies. There is much to advance in sustainability reporting in this sector, especially in relation to transparency and quality of the reports.

Nonetheless, the GRI framework can be an interesting model for the account of the sustainability of electric power companies, because GRI is governed by principles designed to ensure the content and quality of information reported and with a legitimate concern about corporate sustainability. They also provide a supplement to the electricity sector, which, despite not being discussed in this study, has thirty new indicators, and sector-specific comments. Since it is an internationally recognized organization and is constantly evolving, GRI can encourage Brazilian companies to constantly improve their use in order to suit the international standards.

It is also important to remember that external verification of the report has been increasingly appreciated and requested by sustainability indexes and by the most demanding stakeholder groups. This verification, if made by serious institutions, could compensate the freedom provided by GRI.

Since the annual social and environmental report in Brazil is defined by law, we cannot say that the practice of reporting is a voluntary initiative in Brazilian electric sector. The quality of the reports, however, associated with the decision to use a larger number of indicators than ANEEL requires, shows that there are other interests of the companies in reporting their social and environmental performances. 
Camargos M.R. et al.: Analysis of the sustainability reporting initiatives of electric...

One should, however, be aware of how sustainability reports are being used. The business reports should give readers insight into the complexity of management and the companies' dilemmas, what executives think and what is, in fact, the perception of the main public of the corporation. Ideally, companies should produce reports that are closer to journalism than marketing, which would give greater credibility to the information published (Marcondes, 2012).

The GRI is a rich and interesting initiative, which has much to contribute to the transparency of companies towards their stakeholders. However, if proper use and accuracy of the information reported are not guaranteed, it could become just another element of marketing, which will help society obtain the false image of a company concerned with social and environmental issues.

Considering the great influence of the regulatory agency on the content of GRI reports, one suggestion is that ANEEL should adapt its model of socialenvironmental report to the GRI framework, adding to it the more specific indicators, as an attachment. This would facilitate the process of reporting by companies. For the sustainability reports to be a trustworthy document, it will be necessary that ANEEL also checks the content of reports and requires the companies' goals and objectives, by monitoring their evolution over the years.

\section{Acknowledgements}

The authors would like to acknowledge Coordenação de Aperfeiçoamento de Pessoal de Nível Superior (CAPES) and International Energy Initiative (IEI) for the financial support and for making this research possible.

\section{References}

-ANEEL. (2006). Manual de Elaboração do Relatório Anual de Responsabilidade Socioambiental das Empresas de Energia Elétrica. Retrieved from http://www.aneel.gov.br/aplicacoes/leitura_arquivo/default.cfm?idaplicacao=212 2011 Jun 11.

Braga, C. (2011). Fatores determinantes do nível de divulgação ambiental no setor de energia elétrica no Brasil.Advances in Scientific and Applied Accounting, 4(2), 230-262.

Brown, , \& et al., (2009). Building institutions based on information disclosure: lessons from GRI's sustainability reporting.Journal of Cleaner Production, 17(4), 571580.

Calixto, L. (2008). Responsabilidade Socioambiental: Pública ou Privada. Revista Contabilidade Vista e Revista, 19(3), 123-147.

Dow Jones Sustainability Indexes (2012) Retrieved from http://www.sustainabilityindexes.com/ 2012 Jun 24. 
Camargos M.R. et al.: Analysis of the sustainability reporting initiatives of electric...

Elkington, J. (1998). Cannibals with forks: The triple bottom line of 21st century business. Stony Creek, CT: New Society Publishers.

-EPE - Empresa de Pesquisa Energética. (2011). Balanço Energético Nacional 2011: Ano base 2010. Rio de Janeiro.

Grasbois, D. (2012). Corporate social responsibility reporting by the global hotel industry: Commitment, initiatives and performance. International Journal of Hospitality Management, 31, 896-905.

Gray, R. (2010). Is accounting for sustainability actually accounting for sustainability... and how would we know?, An exploration of narratives of organisations and the planet. Accounting, Organizations and Society, 35, 47-62.

-Global Reporting Initiative (GRI). (2006). Sustainability Reporting Guidelines: Version 3.0 GRI. Amsterdam.

Guthrie, J., \& Farneti, F. (2008). GRI sustainability reporting by Australian public sector organizations. Public Money and Management, 28(6), 361-366.

Hedberg, C., \& von Malmborg, F. (2003). The Global Reporting Initiative and corporate sustainability reporting in Swedish companies. Corporate Social Responsibility and Environmental Management, 10(3), 153-164. doi:10.1002/csr.38

-International Institute for Sustainable Development (IISD). (1992). Business Strategies for Sustainable Development. Winnipeg, Canada: IISD.

ISE - Îndice Bovespa de Sustentabilidade (2012) Retrieved from http://www.bmfbovespa.com.br/indices/Resumolndice.aspx?Indice=ISE\&Opcao $=0 \&$ idioma=pt-br 2012 Feb 27.

IUCN, , UNEP, , \& WWF, (1980). World conservation strategy: Living resource conservation for sustainable development. Gland: International union for conservation of nature and natural resources.

Juholin, E. (2004). For business or the good of all? A Finnish approach to corporate social responsibility. Corporate Governance, 4(3), 20-31. doi:10.1108/14720700410547477

Kolk, A. (2010). Trajectories of sustainability reporting by MNCs. Journal of World Business, 45(4), 367-374.

Lamberton, G. (2005). Sustainability accounting-a brief history and conceptual framework. Accounting Forum, 29, 7-26.

Lozano, R., \& Huisingh, D. (2011). Inter-linking issues and dimensions in sustainability reporting. Journal of Cleaner Production, 19, 99-177.

Marcondes, D. (2012). Relatórios de Insustentabilidade. Retrieved from http://www.cartacapital.com.br/carta-verde/relatorios-de-insustentabilidade/ 2012 Apr 4.

The millennium developement goals report (2011) Retrieved from http://www.un.org/millenniumgoals 2011 Aug 15.

Moneva, , \& et al., (2006). GRI and the camouflaging of corporate unsustainability. Accounting Forum, 30, 121-137.

Pereira, , \& et al., (2010). Rural electrification and energy poverty: Empirical evidences from Brazil. Renewable and Sustainable Energy Reviews, 14(4), 1229-1240.

Roca, L.C., \& Searcy, C. (2012). An analysis of indicators disclosed in corporate sustainability reports. Journal of Cleaner Production, 20, 103-118.

Skouloudis, , \& et al., (2010). Assessing non-financial reports according to the Global Reporting Initiative guidelines: evidence from Greece. Journal of Cleaner Production, 18, 426-438. 
Camargos M.R. et al.: Analysis of the sustainability reporting initiatives of electric...

United Nations Global Compact (2011) Retrieved from http://www.unglobalcompact.org 2011 Aug 12.

Yongvanich, K., \& Guthrie, J. (2006). An extended performance reporting framework for social and environmental accounting. Business Strategy and the Environment, 15(5), 309-321. doi:10.1002/bse.541 